\title{
Study of the extract activities of Buas buas leaves (Premna pubescens) as immunostimulant on rats (Rattus novegicus)
}

\author{
Martina Restuati $^{1}$, Syafruddin Ilyas ${ }^{2}$, Salomo Hutahaean $^{2}$, Herbert Sipahutar ${ }^{1}$ \\ ${ }^{1}$ Biology Education Department, Faculty of Mathematic and Science, State University of Medan, Medan, Indonesia \\ ${ }^{2}$ Biology Department, Faculty of Mathematic and Science, University of North Sumatra, Medan, Indonesia \\ Email address: \\ tinaunimed@gmail.com (M. Restuati),Syaf_ilyas2004@yahoo.com (Syafruddin H.), Sal_hutahaean@yahoo.com (S. Hutahaean), \\ herbert_sipahutar@yahoo.com (H. Sipahutar)

\section{To cite this article:} \\ Martina Restuati, Syafruddin Ilyas, Salomo Hutahaean, Herbert Sipahutar. Study of the Extract Activities of Buas buas Leaves (Premna \\ pubescens) as Immunostimulant on Rats (Rattus novegicus). American Journal of BioScience. Vol. 2, No. 6, 2014, pp. $244-250$. \\ doi: 10.11648/j.ajbio.20140206.19
}

\begin{abstract}
Buas buas (Premna pubescens) is one of the plants in Indonesia which is believed to have medicinal properties, but it is not certain. This plant is consumed by the Malay community, one of the tribes in North Sumatra - Indonesia, as vegetables, especially during the fasting month. This paper describes the effects of ethanol extract of leaves of Buas buas as an immunostimulant in rats (Rattus norvegicus). The experiments were performed on 24 tail of male rats, which were three months old, weighing 140-180 g. There were four groups of experiment ie Group $\mathrm{A}_{0}$ was given Carboxy Methyl Cellulose mice (CMC) (control group), group $\mathrm{A}_{1}$ was given $500 \mathrm{mg} / \mathrm{kg}$ bw of Ethanol Extracts of Buas buas. Group $\mathrm{A}_{2}$, given ethanol extracts of Buas buas $500 \mathrm{mg} / \mathrm{kg}$ bw + SRBC, and the group $\mathrm{A}_{3}$ only given Sheep Red Blood Cell (SRBC). After this experiment, apigenin levels were analyzed by High Performance Liquid Chromatography (HPLC) Agilent 1220. Then the activity of immunostimulation is determinated by measuring the leukocyte count, percentage of lymphocytes, antibody titers, the levels of immunoglobulin M (IgM), immunoglobulin G (IgG), and lysozyme with ABX Micros 60 . The group $\mathrm{A}_{2}$ is seen the highest group of in the number of leukocytes, antibody titer levels, imonoglobulin G (IgG), and imonoglobulin M. The amount of lysozyme owned group $\mathrm{A}_{2}$ is 0:04 ug / ml, whereas other treatments to obtain results that are not different relative significantly. Provision of Ethanol Extracts of Buas buas on mice can increase the leukocytes, lymphocytes, antibody titers, IgM, IgG and Lysozyme.
\end{abstract}

Keywords: Premna Pubescens, Titer Antibodies, Lymphocytes, SRBC, IgG, IgM, Lysozyme

\section{Introduction}

The immune system can be improved with the use of traditional medicine. Body's immune system increases the resistance of cells to fight disease. Traditional medicine can be used as treatment efforts (self-medication) to support modern medicine, because the plant is effective in improving the immune system and increase antioxidant activity in humans [1]. One of the plant in Indonesia, which has not been known and used widely, which have medicinal properties, is called Buas buas (Premna pubescens) as shown in Figure 1.

The leaves of this plant are consumed by the Malay community, one of the main tribes in Indonesia, especially North Sumatra just as fresh vegetables or cooked vegetables. The shape of the leaves of this plant looks like Figure 2.

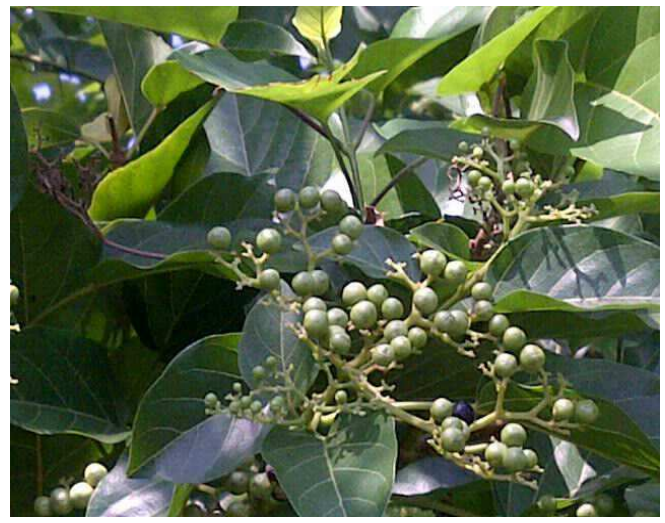

Figures 1. Buas buas Plants (Premna pubescens) 


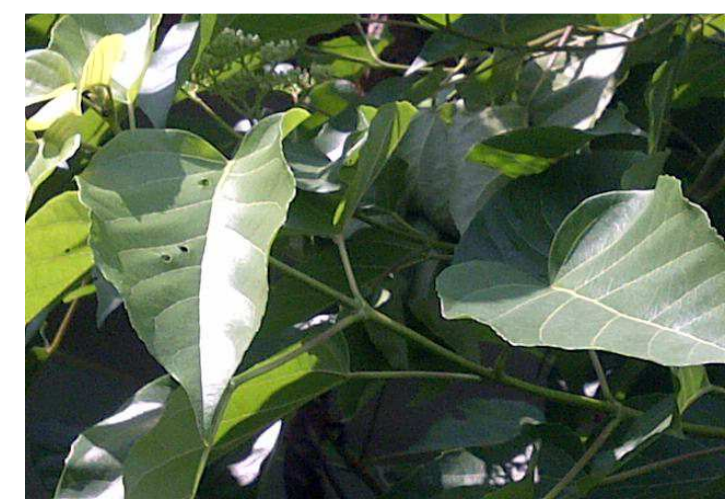

Figure 2. Buas buas Leaf

Some of the other Premna genus has been studied, that related to the content of secondary metabolites owned and usefulness. Corymbosa Premna compounds containing apigenin, which is one of the derivatives of the alkaloid. Secondary metabolites as anti-hyperglycemic activity. The previous research found a significant reduction of total cholesterol, Low Density Lippoproteins (LDL) cholesterol, Very Low Density Lipoproteins (VLDL), and an increase in the High Density lipoproteins (HDL) in adult wistar rats [2]. Apigenin can inhibit, prevent and treat cancer cells. These five common types of flavonoids, are myricetin, kaempferol, quercetin, luteolin and apigenin. Flavonoid apigenin is nontoxic who has the ability as an anti-tumor and chemotherapy agents, and inhibits the growth of vascular endothelial protease inhibitors $[3,4,5]$.

The development of cervical cancer cells ( $\mathrm{H} h \mathrm{La}$ ) in G1 phase can be prevented by lowering the activity of Bcl-2 protein expression by apigenin, which acts as an antiapoptotic [6]. Flavonoid apigenin is nonmutagenik, which prevents the growth of human neuroblastoma cells [7]. This demonstrates the efficacy of Buas buas leaves, which have apigenin compounds can increase of the body's defense system, because it has an activity as an immunostimulant, which can stimulate the immune system non-specific and specific when no antigen. Immunostimulatory consists of biological and synthetic compounds that enhance the body's non-specific defense mechanisms in animals that provide the comprehensive protection [8].

The immunostimulatory activity of the leaves of Buas buas can be measured by several parameters, namely, immunoglobulin $G$ and immunoglobulin $M$ and some hematological parameters such as the percentage of leukocytes, leukocyte count number type, antibody titers, and lysozyme. Lysozyme is one parameter that is measured as the impact of immunostimulant [9]. The immunostimulatory activity can be measured through serological tests and hematology [10]. The immunostimulatory agents can enhance the non-specific immune system such as the number of phagocytic cells, lysozyme and other substances are soluble in serum [11]. This issue became the basis for assessing the role of the ethanol extract of Buas buas leaves as an immunostimulant.

\section{Materials and Methods}

\subsection{Materials and Equipment}

The materials used in this research is the rat feed pellet form PC 05, water (distilled water) were provided ad libitum, wooden hulls as litter of rats, ethanol extract of leaves of Buas buas, Sheep Red Blood Cell (SRBC) antigen, Carboxy Methyl cellulose (CMC). To analyze the serum immunoglobulin is used Elisa Kit Rat IgG and IgM. To analyze Lysozyme levels in serum, is used Lysozyme Kit and HPLC Apegenin Standard. Apigenin is analyzed by ABX Micros 60.

\subsection{The Animal of Test}

A total of twenty-four (24) rats (Rattus norvegicus) wistar strain male, aged 3 months with a weight range of 100-200 g, were used as experimental. The white rats were divided into 4 groups each group had 6 tails. The gender of mice used were male. White rats maintained with acclimatization in groups (two mice per cage) in animal cages made of plastic with a size of $40 \times 30 \times 20 \mathrm{~cm}$. Maintenance is carried out at room temperature $\left(24^{\circ} \mathrm{C}-26^{\circ} \mathrm{C}\right)$. The food is provided in the form of a standard food pellets and water ad libitum.

\subsection{Making of Ethanol Extract of Premna Pubescens Leaf}

The fresh Buas buas leaves as weight as 3420 grams is sorted to separate the leaves from the stalk leaves, insects and other debris. Subsequently these are washed 3 times, then drained. Leaves are already clean dried in drying cabinet to become brittle. The leaves are dried pulverized to obtain powder. Heavy powder obtained is 1050 grams, then extracted using Soxhlet, with $70 \%$ ethanol content. Extract obtained was concentrated with a rotary evaporator and then dried and get dry ethanol extract as much as 195 grams.

\subsection{Antigen Sheep Red Blood Cell (SRBC)}

Making SRBC is started by taking blood from the jugular vein of sheep. Disinfected prior lamb neck with $70 \%$ alcohol before taking blood. Alsever much as $5 \mathrm{CC}$ aspirated and continued to suck blood from the jugular vein of sheep by the same amount $(5 \mathrm{CC}+5 \mathrm{CC}$ alsever sheep blood), using a 10 $\mathrm{CC}$ syringe. Eristrosit is washed with a buffer solution with $\mathrm{pH} 7.4$ kolomer diluent to $40 \mathrm{CC}$, and weighed to obtain a balanced position. Erythrocyte suspension was obtained with a speed of $2000 \mathrm{rpm}$ for 15 min later discard supernatant there. After that, the erythrocyte sedimentation redissolved in kolomer diluent, and centrifuge process is carried back to the velocity and the same deadline. Screening process with centrifuges is done in 3 times, and the results obtained are aspirated using a pasteur pipette. SRBC stored in a tube that is inserted in a refrigerator at a temperature of $40^{\circ} \mathrm{C}$.

\subsection{Screening Apigenin}

The screening Apigenin was done starting from identification of Buas buas plants, testing of the active compound content in plants, and testing the apigenin, which 
used a system of High Performance Liquid Chromatography (HPLC) agilent 1220 with a wavelength of $337 \mathrm{~nm}$, the flow rate of $0.5 \mathrm{ml} / \mathrm{min}$, temperature $25^{\circ} \mathrm{C}$ and injection volume of $10 \mathrm{~mL}$.

\subsection{Experiment Design}

The experiment used a Completely Randomized Design (CRD) non factorial with four treatments, and each was given a six replications. The $\mathrm{A}_{0}$ as a control group was given $0.5 \mathrm{ml}$ of distilled water orally every day. The $\mathrm{A}_{1}$ group was given $250 \mathrm{mg} / \mathrm{kg}$ bw of ethanol extract of leaves of Buas buas without SRBC. The $\mathrm{A}_{2}$ group was given $250 \mathrm{mg} / \mathrm{kg}$ bw of ethanol extract of leaves of Buas buas $+0.1 \mathrm{ml}$ of SRBC and the $\mathrm{A}_{3}$ group was given $0.1 \mathrm{ml}$ SRBC. SRBC given on day 8 and day 15. It refers to the blood samples were obtained from all test animals at the day $31^{\text {st }}$, through the neck decapitation. Serum was separated for measurement of several parameters.

\subsection{Evaluation of Immunostimulants Activity}

Blood samples of mice obtained by decapitation neck in all mice that had been given each treatment on the day $31^{\text {st }}$. Blood collected in the tube which has been given an anticoagulant (EDTA), and then analyzed by using $\mathrm{ABX}$ Micros 60. Hemaglutination method is used to test the antibody titers.

Serum lysozyme activity was measured by following the procedure factory (Sigma Cat Number L7651). Measurement of lysozyme based on the lysis of Micrococcus lysodeiktycus bacteria suspension in accordance with the method developed by [12], namely through the following ways: 0.15 $\mathrm{mg} / \mathrm{ml}$. Micrococcus lysodeiktycus (Sigma) was dissolved in $66 \mathrm{mM}$ PBS (pH 6.2). $50 \mathrm{~mL}$ of serum was added to $1 \mathrm{ml}$ of bacterial suspension. Decrease of absorbance recorded at 0.5 and 4.5 min for 3 minutes on a spectrophotometer with a wavelength of $450 \mathrm{nM}$. One unit of lysozyme activity is defined as a decrease in absorbance of $0.001 \mathrm{~L} / \mathrm{min}$. Determination of $\operatorname{IgG}$ and $\operatorname{IgM}$ is performed with serum dilution treatment, which is done through methods EnzymeLinke d Immunosorbent Assay (ELISA).

\section{Result}

\subsection{Results of Buas Buas Plant Identification and Testing of Bioactive Compounds}

Table 1. The result of phytochemical screening of ethanol extract of Premna pubescens leaves

\begin{tabular}{lc}
\hline Secondary Metabolites & Test result \\
\hline Alkaloid & + \\
Flavonoid & ++ \\
Saponin & ++ \\
Steroid & + \\
\hline
\end{tabular}

Based on the identification of these plants, the Buas buas plants include Verbenaceae, the type of Premna pubescens Blume. The test results showed that the identification of secondary metabolites of the Premna pubescens leaf ethanol extract was positive as alkaloids, flavonoids, saponins, and steroids, as shown in Table 1.

Apigenin assays contained in the ethanol extract of the Premna pubescens leaves, indicates that the pattern of curves owned (Figures 4) almost the same as the standard raw apigenin in Figure 3 . The content of apigenin were analyzed are $0.2845 \mathrm{mcg} / 10 \mathrm{ml} ; 28,45 \mathrm{mcg} / \mathrm{ml}$; dan $35,56 \mathrm{mcg} / \mathrm{ml}$.

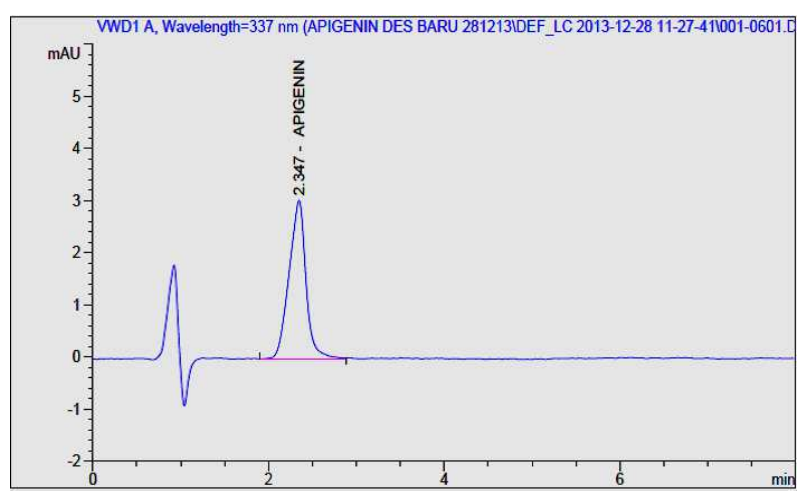

Figure 3. Chromatogram raw apigenin standards

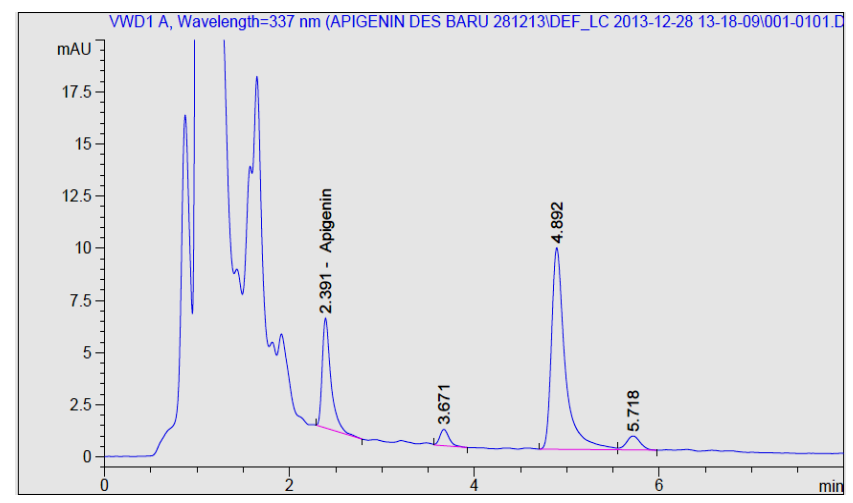

Figure 4. Chromatogram apigenin on ethanol extract of Premna pubescens.

\subsection{Test Results of Immunostimulatory Activity of Premna Pubescens Leaf Ethanol Extract}

Table 2. Effect of ethanol extract of Premna immunostimulatory pubescens leaves against hematocrit and blood hemoglobin mice

\begin{tabular}{lcc}
\hline \multirow{2}{*}{ Treatment } & \multicolumn{2}{c}{ Mean \pm SD } \\
\cline { 2 - 3 } & Hematokrit $(\%)$ & Hemoglobin $(\mathbf{g m} / \mathbf{d l})$ \\
\hline $\mathrm{A}_{0}$ & $36.50 \pm 5.84$ & $11.82 \pm 2.93$ \\
$\mathrm{~A}_{1}$ & $40.95 \pm 4.09$ & $13.60 \pm 0.95$ \\
$\mathrm{~A}_{2}$ & $35.75 \pm 6.19$ & $13.13 \pm 1.26$ \\
$\mathrm{~A}_{3}$ & $42.93 \pm 2.84$ & $14.23 \pm 0.50$ \\
\hline
\end{tabular}

A preliminary description of the effect of ethanol extract of Premna pubescens leaves ie hematocrit and hemoglobin, shown by the average percentage of hematocrit on the $A_{3}$, which had an average of the highest percentages in the amount of $42.93 \%$ (exceeding normal hematocrit values in male rats is $32-40 \%$ ). Hematocrit value in the treatment $\mathrm{A}_{3}$ shows, that the state of the viscosity of blood concentrations higher than the other three treatments. $A_{2}$ treatment had lower hematocrit percentage compared with the $\mathrm{A}_{3}$. Likewise, the concentration of hemoglobin testing, treatment $\mathrm{A}_{3}$ has the 
highest concentration compared with other treatments hasil pengujian shown in Table 2 .

Description: $\mathrm{A}_{0}$ : as a control; $\mathrm{A}_{1}$ : given the ethanol extract of Premna pubescens leaves, $\mathrm{A}_{2}$ : given the ethanol extract of Premna pubescens leaves and SRBC, $\mathrm{A}_{3}$ : given SRBC.

Testing of the effect of Premna pubescens leaves ethanol extract against each concentration of blood cells namely erythrocytes, leukocytes, and platelets showed that blood concentrations of each treatment showed normal concentrations, ie $6.20-7.64 \times 106 / \mathrm{mm}^{3}$. The white rat erythrocytes concentration pattern has the same pattern as the percentage of hematocrit. The treatment $\mathrm{A}_{3}$ has the highest concentration of erythrocytes after $\mathrm{A} 1$ while $\mathrm{A}_{0}$ have the lowest concentration of erythrocytes. The difference in erythrocyte concentrations obtained in all four treatment have not been able to explain in detail the effect of ethanol extract of Premna pubescens leaves against erythrocyte concentrations. This is caused by differences in the four concentrations of erythrocytes is still quite normal and not significantly different.

Leukocyte concentration test results showed the highest concentration of leukocytes is the treatment $A_{3}(9.88 \mathrm{x}$ $\left.103 / \mathrm{mm}^{3}\right)$, while the lowest concentration is in treatment $A_{0}$ $\left(5.50 \times 103 / \mathrm{mm}^{3}\right)$. Treatment $A_{2}$ are also added leukocyte antigen SRBC resulted in lower concentrations than treatment $A_{3}$ yaitu $7: 52 \times 103 / \mathrm{mm}^{3}$. The test results are indicated in Table 3.

Table 3. Effect of ethanol extract of Premna pubescens leaves immunostimulatory against erythrocytes, leukocytes, and platelets

\begin{tabular}{lccc}
\hline \multirow{2}{*}{ Treatment } & \multicolumn{3}{c}{ Mean \pm SD } \\
\cline { 2 - 4 } & Eritrosit $\left(\mathbf{x ~ 1 0} / \mathbf{m m}^{\mathbf{3}}\right)$ & Leukosit $\left(\mathbf{x ~ 1 0} \mathbf{3} \mathbf{m m}^{\mathbf{3}}\right)$ & Trombosit $\left(\mathbf{x} \mathbf{1 0} / \mathbf{m m}^{\mathbf{3}}\right)$ \\
\hline $\mathrm{A}_{0}$ & $6.58 \pm 1.80$ & $5.50 \pm 1.48$ & $6.00 \pm 2.12$ \\
$\mathrm{~A}_{1}$ & $7.41 \pm 0.36$ & $9.82 \pm 1.36$ & $7.35 \pm 1.05$ \\
$\mathrm{~A}_{2}$ & $6.69 \pm 0.26$ & $7.52 \pm 1.82$ & $10.13 \pm 1.61$ \\
$\mathrm{~A}_{3}$ & $7.78 \pm 0.23$ & $9.88 \pm 2.31$ & $8.85 \pm 0.50$ \\
\hline
\end{tabular}

Description: $\mathrm{A}_{0}$ : as a control; $\mathrm{A}_{1}$ : given the ethanol extract of leaves Premna pubescens, $\mathrm{A}_{2}$ : given the ethanol extract of leaves Premna pubescens and SRBC, $\mathrm{A}_{3}$ : given SRBC.

\subsection{Test Count the Number of Leukocytes and Lymphocytes}

The highest number of leukocytes contained in the $\mathrm{A}_{2}$ treatment, ie the treatment given ethanol extracts of Buas buas and SRBC. While the lowest is the number of leukocytes contained in the $A_{1}$ treatment, ie given only ethanol extract of Buas buas. The value of group $\mathrm{A}_{0}$, as a control group, is relatively the same as the value of $A_{2}$. On the treatment given $\mathrm{SRBC}$, namely the $\mathrm{A}_{2}$ group and the $\mathrm{A}_{3}$ group, it seems that the $\mathrm{A}_{3}$ has a number of leukocytes were slightly lower than the $\mathrm{A}_{2}$ group. The results of the calculations are shown in Table 4.

Table 4. Effect of Ethanol Extracts of Buas buas to the count number of leukocytes and lymphocytes.

\begin{tabular}{|c|c|c|}
\hline \multirow{2}{*}{ Group } & \multicolumn{2}{|c|}{ Mean \pm SD } \\
\hline & Leukosit $\left(\times 10^{3} / \mathrm{mm}^{3}\right)\left(\times 10^{3} / \mathrm{mm}^{3}\right)$ & Limfosit (\%) \\
\hline $\mathrm{A}_{0}$ & $9.82 \pm 1.36$ & $76.47 \pm 3.10$ \\
\hline $\mathrm{A}_{1}$ & $5.50 \pm 1.48$ & $71.90 \pm 7.00$ \\
\hline $\mathrm{A}_{2}$ & $9.88 \pm 2.31$ & $74.94 \pm 9.66$ \\
\hline $\mathrm{A}_{3}$ & $7.52 \pm 1.82$ & $61.98 \pm 9.41$ \\
\hline
\end{tabular}

Description: SD: Standard Deviation; $\mathrm{A}_{0}$ : as a control; $\mathrm{A}_{1}$ : given the ethanol extract of leaves Premna pubescens, $\mathrm{A}_{2}$ : given the ethanol extract of leaves Premna pubescens and antigens of sheep red blood cells, $\mathrm{A}_{3}$ : given antigen of sheep red blood cells.

\subsection{Antibody Titer Test}

Table 5. Effect of Ethanol Extracts of Buas buas to the count number and types of leukocytes.

\begin{tabular}{lc}
\hline Treatment & Mean of antibody Titer $(\mathrm{HI}) \pm$ SD \\
\hline $\mathrm{A}_{0}$ & $1.00 \pm 0.89$ \\
$\mathrm{~A}_{1}$ & $1.67 \pm 0.52$ \\
$\mathrm{~A}_{2}$ & $7.17 \pm 0.75$ \\
$\mathrm{~A}_{3}$ & $6.67 \pm 1.51$ \\
\hline
\end{tabular}

Test performed with antibody titers of hemagglutination test that is based on the agglutination of red blood cells. The test results showed antibody titers showed the $\mathrm{A}_{2}$ treatment are the highest values $(7: 17)$ than the other three treatments. Then the antibody titer in the treatment $A_{3}$ is 6.67 . While on $\mathrm{A}_{0}$ and $\mathrm{A}_{1}$ showed antibody titer levels were relatively similar, as shown in Table 5.

Description: SD: Standard Deviation; $\mathrm{A}_{0}$ : as a control; $\mathrm{A}_{1}$ : given the ethanol extract of leaves Premna pubescens, $\mathrm{A}_{2}$ : given the ethanol extract of leaves Premna pubescens and antigens of sheep red blood cells, $\mathrm{A}_{3}$ : given antigen of sheep red blood cells.

\subsection{Mesurement of Imunoglobulin G dan Imunoglobulin $M$}

The measurement results showed that the highest levels of IgM are those of $A_{2}$, which is $3.96 \pm 1: 05 \mathrm{ng} / \mathrm{ml}$, whereas IgM levels were lowest in the control treatment was $0.88 \pm$ A0 is $0: 28 \mathrm{ng} / \mathrm{ml}$. When compared with the treatment added 
SRBC, namely $A_{2}$ and $A_{3}$, both have higher IgM levels than

shown in Table 6. treatment that is added $\mathrm{SRBC}$ ie groups $\mathrm{A}_{0}$ and $\mathrm{A}_{1}$ group, as

Table 6. Effect of ethanol extract of Buas buas to count number and types of leukocytes

\begin{tabular}{lcc}
\hline \multirow{2}{*}{ Treatment } & \multicolumn{2}{c}{ Mean \pm SD } \\
\cline { 2 - 3 } & Immunoglobulin M (ng/ml) & Imunoglobulin G (ng/ml) \\
\hline $\mathrm{A}_{0}$ & $0.88 \pm 0.28$ & $4.52 \pm 1.30$ \\
$\mathrm{~A}_{1}$ & $1.74 \pm 0.57$ & $8.70 \pm 0.83$ \\
$\mathrm{~A}_{2}$ & $3.96 \pm 1.05$ & $9.48 \pm 5.90$ \\
$\mathrm{~A}_{3}$ & $2.20 \pm 1.05$ & $8.96 \pm 3.61$ \\
\hline
\end{tabular}

Description: SD: Standard Deviation; $\mathrm{A}_{0}$ : as a control; $\mathrm{A}_{1}$ : given the ethanol extract of Premna pubescens leaves, $\mathrm{A}_{2}$ : given the ethanol extract of Premna pubescens leaves and antigens of sheep red blood cells, $\mathrm{A}_{3}$ : given antigen of sheep red blood cells.

On testing IgG levels, treatment $\mathrm{A}_{2}$ have the highest levels of $\operatorname{IgG}(9: 48 \pm 5.90 \mathrm{ng} / \mathrm{ml})$, while $\mathrm{A}_{0}$ has the lowest levels of IgG 4:52 $\pm 1: 30 \mathrm{ng} / \mathrm{ml}$. On $A_{1}$ treatment have relatively similar levels of $\mathrm{IgG}$ with $\mathrm{A}_{3}$ is $8.70 \pm 0.83 \mathrm{ng} / \mathrm{ml}$ and $8.96 \pm$ $3.61 \mathrm{ng} / \mathrm{ml}$. Based on the difference in the number of levels obtained, IgM levels lower than IgG.

\subsection{Mesurement of Lisozim Levels}

On lysozyme assay, the three treatments $\left(\mathrm{A}_{0}, \mathrm{~A}_{1}, \mathrm{~A}_{3}\right)$ have an average value unchanged at 0:03 $\mathrm{ng} / \mathrm{ml}$. While on treatment $\mathrm{A}_{2}$ have higher levels ie 0:04 0:01 $\mathrm{ng} / \mathrm{ml}$ as shown in Table 7.

Table 7. Effect of ethanol extract of Buas buas against the percentage of white rat lysozyme

\begin{tabular}{lc}
\hline Treatment & Meanof Lisozim value $(\mu \mathrm{g} / \mathrm{ml}) \pm$ SD \\
\hline $\mathrm{A}_{0}$ & $0.03 \pm 0.02$ \\
$\mathrm{~A}_{1}$ & $0.03 \pm 0.01$ \\
$\mathrm{~A}_{2}$ & $0.04 \pm 0.01$ \\
$\mathrm{~A}_{3}$ & $0.03 \pm 0.02$ \\
\hline
\end{tabular}

Description: SD: Standard Deviation; $\mathrm{A}_{0}$ : as a control; $\mathrm{A}_{1}$ : given the ethanol extract of Premna pubescens leaves, $\mathrm{A}_{2}$ : given the ethanol extract of Premna pubescens leaves and antigens of sheep red blood cells, $\mathrm{A}_{3}$ : given antigen of sheep red blood cells.

\section{Discussion}

Leukocytes are activated cells of the immune system that can respond to antigens that enter the body. On this study, Sheep Red Blood Cell (SRBC) was used as antigen due to the combination with skin proteins qualify as antigens when used to obtain the contact hypersensitivity reaction in mice. It is in base line with Kannan, Singh, kumar, Jegatheswari and Subburayalu (2007). On testing leukocytes known that the highest concentration of leukocytes is at A2 $(9.88 \pm 2.31 \times 103$ $\left./ \mathrm{mm}^{3}\right)$, while the lowest concentration is on the $A_{1}(5: 50 \pm$ $1: 48 \times 103 / \mathrm{mm}^{3}$ ).

The height of the leukocyte concentration in $\mathrm{A}_{2}$ due to the addition of SRBC antigens so that the number of leukocytes increased to fight the antigen into the body of white mice. In addition, the treatment $\mathrm{A}_{2}$ is also added immunostimulatory substance that the ethanol extract of Buas buas mechanism that stimulates the immune system to produce more in the number of leukocytes. The number of leukocytes in the treatment added ethanol extracts of Buas buas and SRBC $\left(\mathrm{A}_{2}\right)$ is almost the same as the control treatment $\left(\mathrm{A}_{0}\right)$. It is clear that when rats fed ethanol extracts of Buas buas for 30 days, added antigen SRBC, condition endurance of mice is similar to the control condition is not added ethanol extracts of Buas buas and antigen SRBC. Overall, each of the number of leukocytes in the four treatment has a normal number of leukocytes ie $4.19-9.73 \mathrm{X} 103 / \mathrm{mm}^{3}$. It is in line with the findings of [13]. Antigen given in treatment $\mathrm{A}_{2}$ and $\mathrm{A}_{3}$, can multiply intracellularly, making it difficult to reach antibody. To combat these intracellular antigens required cellular immune response, which is a function of lymphocytes, especially $\mathrm{T}$ lymphocytes. The helper $\mathrm{T}$ cells will recognize microorganisms or antigen via MHC class II found on the cell surface of macrophages. This signal is triggered lymphocytes to produce various types of lymphokines which can help the macrophages destroy microorganisms, that is in line with findings of [14].

The results show that the number of lymphocytes in the treatment $\mathrm{A}_{0}$, is the highest among the three other treatments ie $76.47 \pm 3: 10 \%$, while the percentage of lymphocytes that at least is at $\mathrm{A}_{3}$ treatment. The low percentage of lymphocytes in $\mathrm{A}_{3}$ caused by the administration of SRBC antigens, are not added immunostimulatory substances such as in the commission of $\mathrm{A}_{2}$. So when the antigen is given without adding immunostimulatory substances, the body is not stimulated to produce more antibodies. On the $\mathrm{A}_{2}$ treatment, administration of antigen followed by the addition of immunostimulatory substances will increase the production of immunoglobulin and approaching the normal value is 76$98 \%$, in line with [13].

On antibody titer testing, measurements on changes in the number of antibodies in an immune response in the body that the highest antibody titers found in $\mathrm{A}_{2}$ treatment, which is treatment given immunostimulatory substances such as apigenin in ethanol extracts of Buas buas and antigen SRBC. Given antigen triggers the body's immune system to produce antibodies. In addition, the treatment is added antigen $\left(\mathrm{A}_{2}\right.$ and $\left.A_{3}\right), A_{2}$ has a higher antibody titers value than $A_{3}$ is also caused by the presence of immunostimulatory substances that help increase the production of antibodies, thereby reducing the duration of the inflammatory reaction. It is in line the 
statement of [15], that the increase of humoral response due to SRBC showed an increase in the responsiveness of macrophages, and $\mathrm{B}$ and $\mathrm{T}$ lymphocytes in antibody synthesis. This is also consistent with the results obtained in the percentage of lymphocytes in the treatment of A2 (74.94 $\pm 9.66 \%)$ higher than A3 $(61.98 \pm 9.66 \%)$.

Imunoglubulin $\mathbf{M}$ is used as a parameter in this study because it is the first time that antibodies present in the immune response to the antigen and the primary antibody in blood group naturally in accordance with the opinion of [16]. The results show that the highest levels of $\operatorname{IgM}$ is in $\mathrm{A}_{2}$ (1:05 $\pm 3.96 \mathrm{ng} / \mathrm{ml}$ ) is the treatment given immunostimulatory substance ethanol extracts of Buas buas and SRBC. While only added SRBC treatment and no immunostimulatory substance $\left(\mathrm{A}_{3}\right)$ have lower levels of $\operatorname{IgM}(2: 20 \pm 1: 05 \mathrm{ng} / \mathrm{ml})$. High levels of IgM in $\mathrm{A}_{2}$ shows that the immunostimulatory substances such as apigenin in ethanol extracts of Buas buas can increase the production of IgM. Similarly, immunoglobulin $G$, is used as a parameter of this study, because the percentage of immunoglobulin $\mathrm{G}$ has at most percentage is about $75 \%$ of the total immunoglobulins. This is in line with the opinions of [16]. The test results also show that $\mathrm{A}_{2}$ has the highest levels of $\mathrm{IgG}$ is $9: 48 \pm 5.90 \mathrm{ng} / \mathrm{ml}$. The lowest level of $\operatorname{IgG}$ and $\operatorname{IgM}$ was on the treatment $\mathrm{A}_{0}$, ie $0.88 \pm 0: 28 \mathrm{ng} / \mathrm{ml}$ and 4:52 $\pm 1: 30 \mathrm{ng} / \mathrm{ml}$. In [14] is explained that the appearance of antibodies in the form of immunoglobulins in the blood due to the differentiation of $\mathrm{B}$ lymphocytes, antibodies that bind to the antigen forming antigen-antibody complexes can activate complement and lead to the destruction of the antigen. In order to differentiate B lymphocytes, and make antibodies, its' needed the help of $\mathrm{T}$ lymphocytes by certain signals through MHC and signals released by macrophages stimulates the production of antibodies. The percentage of lymphocytes in $\mathrm{A}_{2}$ treatment also showed a higher percentage of lymphocytes than $A_{3}$ treatent.

Other parameters are used to determine the effect of immunostimulatory substances in the body of the rat is lysozyme. It is used in line with the statement of [11], that lysozyme can enhance the body's non-specific defense system. From these experiments it is known that the treatment $\mathrm{A}_{2}$ has the highest levels of lysozyme $(0: 04 \mathrm{ug} / \mathrm{ml})$, while the other treatments showed similar values ie 0:03 ug/ml. Lysozyme protects several places in the body which is a potential place for food for bacterial growth. In the blood, lysozyme provides protection, with a more powerful method to that used by the immune system.

Immunostimulatory bind specific receptors on the surface membrane of phagocytes and lymphocytes, which activate these cells to produce several enzymes including lysozyme to destroy pathogens are like the opinion of [17]. On this basis, it can be stated that the ethanol extract of Buas buas is to be as antibacterial as reported by [18].

\section{Acknowledgement}

The author is very grateful to Hamonangan Tambunan,
Lecturer of Electrical Engineering Education Department, Faculty of Engineering, State University of Medan. He gives a lot of relief to the author.

\section{References}

[1] Lie, T., et. all., 2010. Flavonoid, Phenol and Polysaccharide Contents of Echinacea purpurea $L$. and Its Immunostimulant Capacity In Vitro. International Journ. of Environmental Science and Development. Vol. 1 No. 1 . http://dx.doi.org/10.7763/ijesd.2010.v1.2

[2] Thiruvenkatasubramaniam, R., Jayakar, B. 2010. Antihypreglycemic and anti-hyperlipidemic activities of Premna corymbosa (Burm.F) Rottl on Streptozotocin induced diabetic rats. Der Pharmacia Lettre. 2 (1) 505-509.

[3] Gates M.A, Vitonis, A.F, Tworoger S.S, Rosner, B, Ernstoff, L.T, Hankinson, S.E, dan Cramer D.W, 2009. Flavonoid intake and ovarium cancer risk in a Polution based casecontrol study. International Journal of Cancer. 124, 19181925. http://dx.doi.org/10.1002/ijc.24151.

[4] Chen, D., Piwowar, K.R.L., Chen, M.S., Dou, Q.P, 2007. Inhibition of Proteasome Activity by the Dietary Flavonoid Apigenin is Associated with Growth Inhibition in Cultured Breast Cancer Cells and Xe7nografts. Breast Cancer Research. 9. 1-8. http://dx.doi.org/10.1186/bcr1797.

[5] Fang, J., Xia, C., Cao. Z., Zheng, J.Z., Reed, E., dan Jiang, B.H. 2005. Apigenin inhibits VEGF and HIF-1 expression via P13K/AKT/ p7056K1 and HDM2/p53 pathways. The FASEB journal.19. 342-353. http://dx.doi.org/10.1096/fj.04-2175com

[6] Zheng. P.W, Chiang. L.C, Lin, C.C. 2005. Apigenin Induced Apoptosis through p53-dependent pathway in human Cervikal Carcinova Cells. Life Science. Volume 76. Issue 12. http://dx.doi.org/10.1016/j.lfs.2004.08.023

[7] Torkin R. Lavoie JF. Kaplan DR. Yeger H (2005). Induction of Caspase-Dependent, P-53 Mediated Apoptosis by Apigenin in Human Neuro blastoma. Molecolar Cancer Theurapetic. Vol 4. Edition 1. American Association for Cancer research.

[8] Bairwa, M.K., Jakhar, J.K., Y. Satyanarayana., Reddy, A.D, 2012. Animal and Plant Originated Immunostimulants Used in Aquaculture. Journal of Natural Product and Plant Resource. 2 (3): 397-400.

[9] Ogier de Baulny, M., Quentell, C., Vournier, V. Lamour, F and R. Guevello. 1996. Effect of long-term oral administration of $\beta$-glucan as an immunostimulant or an adjuvant on some nonspecific parameters of the immune response of turbot Scophthalmus maximus. Diseases of aquatic organisms. Vol 26: 139 - 147. http://dx.doi.org/10.3354/dao026139

[10] Khumar, S., Gupta, P., Sharma S. and D Khumar. 2011. A Review on Immunostimulatory plant. Journal of Chinese Integrative Medicine. Vol. 9 No.2: 117-128. http://dx.doi.org/10.3736/jcim20110201.

[11] Jian, J dan Wu, Z. 2004. Influence of Traditional Chinese Medicine on Non-Specific Immunity of Jian Carp (Cyprinus carpio var. Jian). Fish and Shellfish Immunology. 16. 185-191. http://dx.doi.org/10.1016/s1050-4648(03)00062-7.

[12] Ellis, A. 1988. Fish faccination. Academic Press, San Diego, C.A. USA. $1-16$ 
[13] Charles River Laboratories, 1998. Baseline Hematology and Clinical Chemistry Value for Charles River Wistar Rats-(CRL: (WI) BR) as a Function of Sex and Age. Technical Bulletin.

[14] Siahaan, P.M. 2010. Immunologi. FMIPA UNIMED. Medan.

[15] Farhath, S., Vijaya dan Vimal. 2013. Immunomodulatory activity of geranial acetate, gingerol, and eudenol essential oils: evidence for humoral and cell-mediated responses. Avicenna Journal of Phytomedicine. 1-7.

[16] Roitt, I. 2001. Roitt's Essential Immunology, $8^{\text {th }}$ ed.Blackwell Science.
[17] Kannan, M., Singh, A.R., Kumar, T.A., Jegatheswari, P., dan Subburayalu, S. 2007. Studies on Immuno-bioactivities of Nyctanthes arbortritis (Oleacea). African Journal of Microbiology Research, 1 (6). 088-091.

[18] Shiney, R.B, Ganesh P, and R. S. Khumar. 2012. Phytochemical Screening of Coleus aromaticus and Leucas aspera and Their Antibacterial Activity against Entheric Phatogens. International Journal of Pharmaceutical and Biological Archives. 3(1): 162-166. 